\title{
Marine Algal Toxins: Origins, Health Effects, and Their Increased Occurrence
}

\begin{abstract}
Frances M. Van Dolah South Carolina USA

Certain marine algae produce potent toxins that impact human health through the consumption of contaminated shellfish and finfish and through water or aerosol exposure. Over the past three decades, the frequency and global distribution of toxic algal incidents appear to have increased, and human intoxications from novel algal sources have occurred. This increase is of particular concern, since it parallels recent evidence of large-scale ecologic disturbances that coincide with trends in global warming. The extent to which human activities have contributed to their increase therefore comes into question. This review summarizes the origins and health effects of marine algal toxins, as well as changes in their current global distribution, and examines possible causes for the recent increase in their occurrence. Key words: amnesic shellfish poisoning, diarrhetic shellfish poisoning, dinoflagellates, domoic acid, global climate change, harmful algal blooms, marine toxins, neurotoxic shellfish poisoning, okadaic acid, paralytic shellfish poisoning. - Environ Health Perspect 108(suppl 1):133-141 (2000).

http://ehpnet1.niehs.nih.gov/docs/2000/suppl-1/133-141vandolah/abstract.htm/
\end{abstract}

Marine Biotoxins Program, NOAA National Ocean Service, Center for Coastal Environmental Health and Biomolecular Research, Charleston,

Marine algal toxins are responsible for an array of human illnesses associated with consumption of seafood and, in some cases, respiratory exposure to aerosolized toxins. Approximately $20 \%$ of all foodborne disease outbreaks in the United States result from the consumption of seafoods, with half of those resulting from naturally occurring algal toxins (1). On a worldwide basis, marine algal toxins are responsible for more than 60,000 intoxication incidents per year, with an overall mortality rate of $1.5 \%$. In addition to their human health effects, algal toxins are responsible for extensive die-offs of fish and shellfish and have been implicated in the episodic mortalities of marine mammals, birds, and other animals dependent on the marine food web. The impacts of algal toxins are generally observed as acute intoxications, whereas the environmental health effects of chronic exposure to low levels of algal toxins are only poorly documented and are an emerging issue (2-5).

The origins of marine algal toxins are unicellular algae that, in response to favorable conditions in their environment, may proliferate and/or aggregate to form dense concentrations of cells or "blooms." In many cases, toxic species are normally present in low concentrations, with no environmental or human health impacts; toxicity in general depends on their presence in high cell concentrations. Phytoplankton species that produce toxins, currently included under the broad term harmful algal blooms (HABs), previously were called red tides. Only about 2\% (60-80 species) of the estimated 3,400-4,000 known phytoplankton taxa are harmful or toxic (6). Of these, members of two algal groups, the dinoflagellates and diatoms, produce toxins that impact humans. Filter-feeding shellfish, zooplankton, and herbivorous fishes ingest these algae and act as vectors to humans either directly (e.g., shellfish) or through further food web transfer of sequestered toxin to higher trophic levels. Consumption of seafood contaminated with algal toxins results in five seafood poisoning syndromes (Table 1): paralytic shellfish poisoning, neurotoxic shellfish poisoning, amnesic shellfish poisoning, diarrhetic shellfish poisoning, and ciguatera fish poisoning. Most of these toxins are neurotoxins and all are temperature stable, so cooking does not ameliorate toxicity in contaminated seafoods. In addition to foodborne poisonings, toxins from two dinoflagellate sources are aerosolized (brevetoxins) or volatilized (a putative Pfiesteria toxin) to impact human health through the respiratory route.

Over the past three decades, the occurrence of harmful or toxic algal incidents has increased in many parts of the world, both in frequency and in geographic distribution (7-9). There are many contributing factors to this expansion, not the least of which is increased awareness of the issues and consequent establishment of research programs and surveillance systems, which in turn have helped identify problems not previously recognized. In certain instances, however, the expansion of toxic algal blooms to new geographic areas, resulting in human illness or environmental impacts, is well documented. There has been much speculation about the causes and significance of the observed expansion; however, few definitive studies have been carried out to date. Of particular concern is determining whether the apparent increase in harmful and toxic algal blooms is a consequence of anthropogenic activities, which might therefore be modified to reverse the current trends. Human activities may contribute to the problem directly or indirectly through the introduction of nonindigenous species via ballast water transport or shellfish transplantation, local and regional environmental change caused by eutrophication or contaminant loading, large-scale climate fluctuations (anomolous weather events; El Niño), and global climate change mediated by the anthropogenic increase in greenhouse gases. In this review, we first summarize the origins, health effects, and changes in global distribution of each of the toxin classes of human health significance, and then consider the current status of our understanding of the causes and implications of their increased occurrences. The review does not attempt to address nuisance blooms or freshwater algal toxins, which can be found in previous reviews on the global increase in harmful algal blooms (8-13).

\section{Paralytic Shellfish Poisoning}

Paralytic shellfish poisoning (PSP) is caused by the consumption of molluscan shellfish contaminated with a suite of heterocyclic guanidines collectively called saxitoxins (STXs) (Figure 1A). On a global basis, almost 2,000 cases of human poisonings are reported per year, with a $15 \%$ mortality rate (8). In addition to human intoxications, PSP has been implicated in deaths of birds (14) and humpback whales (15). An ecologic role for PSP toxins as a chemical defense is suggested by the sequestration of PSP toxins in the butter clam, modulation of feeding behavior in sea otters by toxic clams, and a distribution of Alaskan sea otters that coincides with nontoxic clam populations $(16,17)$.

STX elicits its effects by binding with high affinity $\left(K_{d}-2 \mathrm{nM}\right)$ to site 1 on the voltage-dependent sodium channel, inhibiting channel conductance and thereby causing blockade of neuronal activity. The primary site of STX action in humans is the peripheral nervous system, where its binding results in rapid onset of symptoms (less than $1 \mathrm{hr}$ ) that are classic for PSP: tingling and numbness of the perioral area and extremities, loss of motor control, drowsiness, incoherence, and in the case of high doses, respiratory paralysis. The lethal dose in humans is

Address correspondence to F.M. Van Dolah, Marine Biotoxins Program, NOAA National Ocean Service, Center for Coastal Environmental Health and Biomolecular Research, 219 Fort Johnson Rd. Charleston, SC 29412. Telephone: (843) 762-8529. Fax: (843) 762-8700. E-mail: fran.vandolah@noaa.gov

Received 6 October 1999; accepted 19 November 1999. 
Table 1. Toxic syndromes associated with marine algal toxins.

\begin{tabular}{|c|c|c|c|c|}
\hline Syndrome & Causative organism & Primary vector & Toxin & Pharmacologic target \\
\hline PSP & $\begin{array}{l}\text { Alexandrium spp. } \\
\text { Gymnodinium spp. } \\
\text { Pyrodinium spp. }\end{array}$ & Shellfish & Saxitoxins & $\begin{array}{l}\text { Voltage-dependent sodium channel } \\
\text { Site } 1\end{array}$ \\
\hline NSP & Gymnodinium breve & Shellfish & Brevetoxins & $\begin{array}{l}\text { Voltage-dependent sodium channel } \\
\text { Site } 5\end{array}$ \\
\hline CFP & Gambierdiscus toxicus & Reef fish & Ciguatoxins & $\begin{array}{l}\text { Voltage-dependent sodium channel } \\
\text { Site } 5\end{array}$ \\
\hline ASP & Pseudo-nitzschia spp. & Shellfish & Domoic acid & Glutamate receptors \\
\hline DSP & $\begin{array}{l}\text { Dinophysis spp. } \\
\text { Prorocentrum spp. }\end{array}$ & Shellfish & $\begin{array}{l}\text { Dinophysistoxins } \\
\text { Okadaic acid }\end{array}$ & Ser/thr protein phosphatases \\
\hline $\begin{array}{l}\text { Estuary } \\
\text { syndrome }\end{array}$ & Pfiesteria piscicida & Water & Unknown & Unknown \\
\hline
\end{tabular}

A

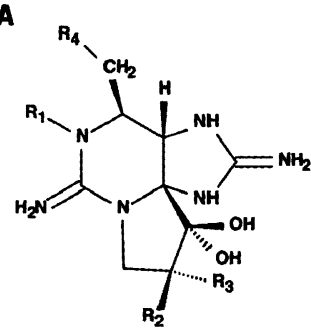

B

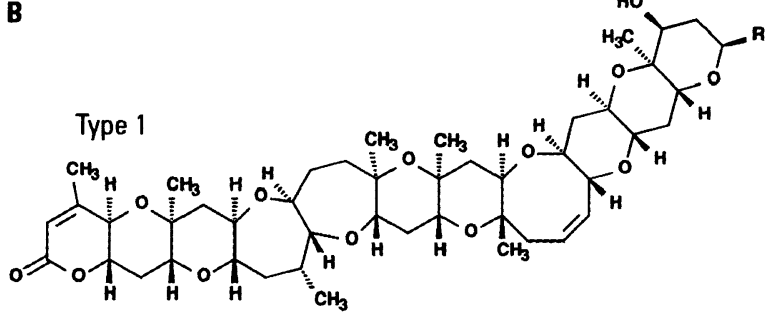

C

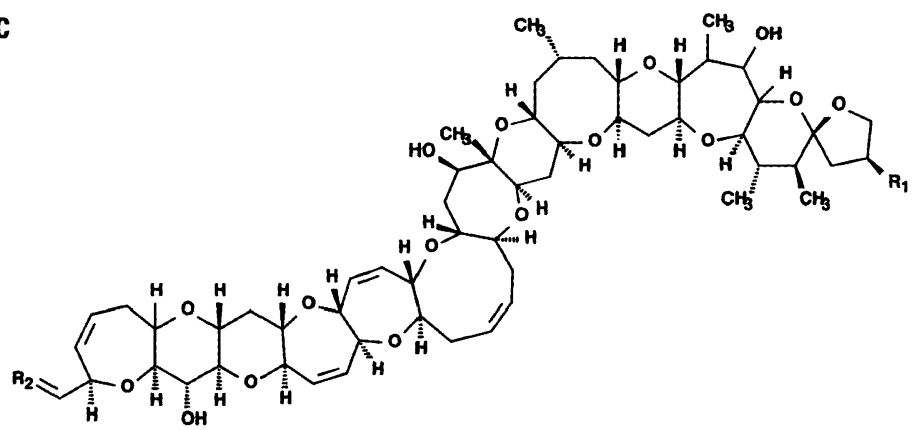

D<smiles>CC1=CC2(OC(C[C@](C)(O)C(=O)O)CC=C2O)OC(C(C)C)CC1C</smiles>

Figure 1. Marine algal toxins that impact human health. $(A)$ Saxitoxin, $(B)$ brevetoxin, $(C)$ ciguatoxin, $(D)$ okadaic acid, (E) domoic acid.
1-4 mg STX equivalents (18). Since shellfish may on rare occasions contain greater than $10,000 \mu \mathrm{g} / 100 \mathrm{~g}$ STX equivalents, ingestion of only a few shellfish meats may in these instances be fatal. In a study of a PSP outbreak in Kodiak, Alaska, clearance of PSP toxins from the blood was complete in $<24 \mathrm{hr}$, even in patients who experienced respiratory paralysis (19). The primary route of clearance was the kidney, as has also been demonstrated in rats (20) and cats (21). There are currently over 21 known STX congeners that are produced in varying combinations and proportions by several gonyaulacoid and gymnodinioid dinoflagellate species in three genera: Alexandrium, Gymnodinium, and Pyrodinium.

PSP-producing dinoflagellates occur in both temperate and tropical waters. In North America, PSP occurs seasonally both on the east coast (Newfoundland to Massachusetts) and on the west coast (Alaska to California). Anecdotal reports identify PSP in both regions well before this century. Prior to the 1970s PSP was known to be endemic only to North America, Europe, and Japan, whereas, currently, PSP outbreaks are also documented in South America, Australia, Southeast Asia, and India (8). The reasons for this expansion into the southern hemisphere, or in some cases whether these in fact represent expansions of geographic ranges of toxic organisms, are not entirely clear. The first confirmed outbreak of PSP in South America occurred in Chile in 1972 and was associated with a bloom of Alexandrium catenella. Subsequent outbreaks occurred in 1981 and 1989 (22). Since 1991, 21 fatalities and several hundred intoxications have occurred in Chile (23). A similar pattern of increased occurrence of PSP is reported in Argentina, where the first PSP outbreak, which occurred in 1980 , was associated with a bloom of Alexandrium tamarense. Following sporadic outbreaks during the 1980s, shellfish toxicity associated with PSP has been an annual occurrence throughout the 1990s along the Argentine coast (24). As in North America, however, anecdotal stories suggest that PSP occurred in both Chile (22) and Argentina (25) in the last century, an indication that the recent increase in reported PSP events may be attributed at least in part to the establishment of algal and shellfish monitoring programs.

A similar scenario occurred over the past two decades in the Indo-Pacific. The causative organism for Indo-Pacific PSP intoxications is Pyrodinium bahamense var. compressum. The first reported outbreak of PSP in this region occurred in 1972 in Papua New Guinea and subsequently spread to Brunei beginning in 1976, central Philippines in 1983, northern Philippines in 1987, and Malaysia in 1988. In the Philippines alone, 
approximately 2,000 cases of PSP occurred between 1983 and 1998, with a mortality rate of $5.8 \%$; most cases occurred among the young ( $<20$ years of age) (26). The expansion of Pyrodinium blooms in this region appears to be a range extension in at least some of these instances, as it is absent from phytoplankton records in the Philippines prior to the initial PSP outbreak in 1983 (27). There is compelling evidence to suggest that the expansion of toxic blooms of Pyrodinium in the tropical Pacific may correlate with the occurrence of El Niño-Southern Oscillation events (28).

Recurrent PSP events in Tasmania and southern Australia associated with the dinoflagellate Gymnodinium catenatum began in late 1985 (8). The absence of cysts from sediments before 1972 suggests that this species was introduced to the region around that time (29). In this case, the route of introduction has been proposed to be ballast water transport from Japan or Europe, as viable cysts have been isolated from vessel ballast water arriving in Tasmania (30). However, genetic analysis of Tasmanian and Australian strains has not unequivocally identified their geographic origins (31).

\section{Neurotoxic Shellfish Poisoning}

Neurotoxic shellfish poisoning (NSP) generally results from consumption of molluscan shellfish contaminated with brevetoxins $(\mathrm{PbTx})$, a suite of nine structurally related ladderlike polycyclic ether toxins (Figure 1B). Brevetoxin congeners are of two types based on backbone structure: brevetoxin B backbone (type 1; PbTx-2,3,5,6,8,9) and brevetoxin A backbone (type 2; PbTx-1,7,10).

Brevetoxins bind with high affinity $\left(K_{d}\right.$ $1-50 \mathrm{nM})$ to site 5 on the voltage-dependent sodium channel (32). Binding to this site both alters the voltage sensitivity of the channel, resulting in inappropriate opening of the channel under conditions in which it is normally closed, and inhibits channel inactivation, resulting in persistent activation or prolonged channel opening. This complex action is believed to result from the intercalation of the brevetoxin polyether backbone between transmembrane domains of the sodium channel such that it interacts with both the voltage sensor near the outside of the channel and the inactivation gate on the intracellular side (33-37). Symptoms of NSP include nausea, tingling and numbness of the perioral area, loss of motor control, and severe muscular ache. Steidinger et al. (38) examine an unusually severe intoxication of young children that occurred because of consumption of contaminated clams (Chione cancellata) and resulted in seizures and unconsiousness. Unlike PSP, NSP has not been documented as a fatal intoxication in humans.
The occurrence of NSP has historically been limited to the west coast of Florida, where blooms of the dinoflagellate Gymnodinium breve initiate offshore and are subsequently carried inshore by wind and current conditions (39). Gulf of Mexico $G$. breve blooms are occasionally carried around the Florida peninsula by the Loop Current and northward by the Gulf Stream, resulting in red tides on the east coast of Florida and, in a single incident in 1987 , as far north as North Carolina (40). The unprecedented red tide in North Carolina, which resulted in over 48 cases of shellfish poisoning, was supported by a shoreward intrusion of warm Gulf Stream water onto the narrow continental shelf which remained intact in nearshore waters for several weeks (41). Although the 1987 outbreak of $G$. breve is often cited as a range extension, low but consistent background concentrations of $G$. breve are routinely found in the Gulf Stream in the South Atlantic Bight (42). Therefore, the 1987 bloom in North Carolina may be the result of the concurrence of a large-scale sea surface temperature anomaly and local conditions (43) rather than being a true range extension of the organism. In 1993, an unprecedented outbreak of shellfish toxicity in New Zealand was identified as NSP. The source organisms of toxins in this outbreak were novel Gymnodinium species (referred to as Gymnodinium cf. breve) that produce NSP-like toxins (44).

Unlike most other dinoflagellates responsible for seafood poisonings, $G$. breve is an unarmored dinoflagellate that is easily lysed in turbulent water. $G$. breve red tides therefore are frequently associated with massive fish kills. The extreme sensivity of fish to the Florida red tide may result from lysis of cells passing through the gills, with direct transfer of toxin across the gill epithelium. An additional route of human exposure to brevetoxins is similarly through respiration, in this case of aerosolized toxin, which is the result of cells breaking due to wave action. A common symptom associated with exposure to aerosolized brevetoxin is irritation and burning of the throat and upper respiratory tract. In 1996 at least 149 manatees died during an unprecedented epizootic in Florida concurrent with a persistent red tide. Immunohistochemical staining of tissues from affected animals revealed brevetoxin immunoreactivity in lymphocytes and macrophages associated with inflammatory lesions of the respiratory tract and with lymphoid tissues (45). Molecular modeling studies have implicated brevetoxin as an inhibitor of a class of lysosomal proteases, the cysteine cathepsins, which are important in antigen presentation (46). The demonstration of brevetoxin immunoreactivity in lymphoid tissue of the manatees raises the possibility of immunosuppression as a second mode by which brevetoxin exposure may affect human health, particularly in individuals with chronic exposure to aerosolized toxin during prolonged red tide incidents.

\section{Ciguatera Fish Poisoning}

Ciguatera fish poisoning (CFP) is another seafood intoxication caused by ladderlike polyether toxins, primarily attributed to the dinoflagellate, Gambierdiscus toxicus (47), which grows as an epiphyte on filamentous macroalgae associated with coral reefs and reef lagoons. The lipophilic precursors to ciguatoxin produced by $G$. toxicus enter the food web when these algae are grazed upon by herbivorous fishes and invertebrates. These precursors are biotransformed to ciguatoxins (48) and bioaccumulated in the highest trophic levels. Large carnivorous fishes associated with coral reefs are a frequent source of ciguatera. Baracuda, snapper, grouper, and jacks are particularly notorious for their potential to carry high toxin loads; however, smaller herbivorous fishes may also be ciguatoxic, particularly when viscera are consumed. CFP is estimated to affect over 50,000 people annually and is no longer a disease limited to the tropics because of travel to the tropics and shipping of tropical fish species to markets elsewhere in the world (1). The symptoms of ciguatera vary somewhat geographically as well as between individuals and incidents and may also vary temporally within an area, but they generally include early onset $(2-6 \mathrm{hr}$ ) gastrointestinal disturbance-nausea, vomiting, and diarrhea - and may be followed by a variety of later onset (18-hr) neurologic sequelae such as numbness of the perioral area and extremities, reversal of temperature sensation, muscle and joint aches, headache, itching, tachycardia, hypertension, blurred vision, and paralysis. Ciguatera on rare occasions can be fatal. A chronic phase may follow acute intoxication and can persist for weeks, months, or even years (49). Ciguatera symptoms in the Caribbean differ somewhat from those in the Pacific; gastrointestinal symptoms dominate in the former, whereas in the latter neurologic symptoms tend to dominate. This may reflect geographic differences in the toxin congeners involved (50).

The ciguatoxins (CTXs) (Figure 1C) are structurally related to the brevetoxins and compete with brevetoxin for binding to site 5 on the voltage-dependent sodium channel with a high affinity $\left(K_{d}-0.04-4 \mathrm{nM}\right)(51)$. The minimum toxicity level to humans is estimated at $0.5 \mathrm{ng} / \mathrm{g}$ (52). Among the CTX congeners, binding affinity correlates well with toxic potency intraperitoneally in mice. However, the toxic potency of CTX in mice is several orders of magnitude greater than that of the brevetoxins relative to their 
binding affinities at the sodium channel (e.g., for CTX1 and $\mathrm{PbTx} 3, \mathrm{LD}_{50}=0.25 \mu \mathrm{g} / \mathrm{kg}$ vs $>200 \mu \mathrm{g} / \mathrm{kg}$, whereas $K_{d}=0.04 \mathrm{nM}$ vs 2 $\mathrm{nM}$, respectively). This may be related to differences in the bioavailability of the toxins or to undefined toxic effects of ciguatoxin.

Although CFP occurs persistently at certain locations, outbreaks are sporadic and unpredictable at others. Reef disturbance due to storm damage or human activities frequently precedes ciguateric conditions $(53,54)$. The overgrowth of corals by macroalgae because of coral bleaching, overfishing, or nutrient enrichment $(55,56)$ may also promote ciguateric conditions by providing increased substrate for the epiphytic $G$. toxicus. Changes in sea surface temperature associated with El Niño events also appear to correlate with localized changes in the frequency of ciguatera cases in the Asian Pacific (57).

\section{Diarrhetic Shellfish Poisoning}

Diarrhetic shellfish poisoning (DSP) is a comparatively milder seafood intoxication that consists of rapid onset $(3 \mathrm{hr})$ gastrointestinal symptoms such as vomiting and diarrhea that generally resolve within 2-3 days. The diarrhetic shellfish toxins (DTX) are a class of acidic polyether toxins consisting of at least eight congeners including the parent compound, okadaic acid (Figure 1D). The first incidence of human shellfish-related illness identified as DSP occurred in Japan in the late 1970s, where the dinoflagellate Dinophysis fortii was identified as the causative organism; the toxin responsible was termed dinophysistoxin (DTX-1) $(58,59)$. DSP is widespread in its distribution, with essentially seasonal occurrences in Europe and Japan, but it has also been documented in South America, South Africa, New Zealand and Australia, and Thailand. The first confirmed incidence of DSP in North America occurred in 1990 in Nova Scotia, Canada. The causative organism in this outbreak was the benthic dinoflagellate, Prorocentrum lima $(60,61)$, which was found in association with filamentous algae growing on raft cultures of mussels. Toxic $P$. lima was recently identified in Maine coastal waters, where the presence of DSP has been suspected (62). P. lima is a cosmopolitan dinoflagellate, with a range that extends from temperate waters to tropical reefs.

Okadaic acid, DTX-1, and DTX-2 are the primary congeners involved in shellfish poisoning, with the other congeners believed to be either precursors or shellfish metabolites of the active toxins. The DTXs are inhibitors of ser/thr protein phosphatases. Inhibitory activity against protein phosphatases is selective for classes PP2A (okadaic acid $\mathrm{IC}_{50}-0.5 \mathrm{nM}$ ) and PP1 (okadaic acid $\mathrm{IC}_{50}-50 \mathrm{nM}$ ), with PP2B being inhibited only at high concentrations (okadiac acid
$\left.\mathrm{IC}_{50}>10 \mu \mathrm{M}\right)$ and PP2C being insensitive. The binding site for okadaic acid resides on the catalytic subunit of the protein phosphatase at the active site of the ezyme, as determined by X-ray crystal structures (63), molecular modeling (64), and mutational analyses (65). Ser/thr protein phosphatases are critical components of signaling cascades in eukaryotic cells that regulate a diverse array of cellular processes involved in metabolism, ion balance, neurotransmission, and cell cycle regulation (66). Diarrhea associated with DSP is most likely due to the hyperphosphorylation of proteins, including ion channels, in the intestinal epithelia (67), resulting in impaired water balance and loss of fluids. The toxic potency of okadaic acid is much lower than that of the neurotoxin polyethers, with an $\mathrm{LD}_{50}$ of $192 \mu \mathrm{g} / \mathrm{kg}$ (intraperitoneally) in mice (68). However, okadaic acidlike polyether toxins have been identified as tumor promotors $(69,70)$, thus raising the question of what effect low levels of chronic exposure to DSP toxins may have on humans as well as wildlife such as marine turtles (3).

\section{Amnesic Shellfish Poisoning}

Amnesic shellfish poisoning (ASP) is the only shellfish intoxication caused by a diatom. The first recorded occurrence of ASP was in Prince Edward Island, Canada in 1987 when approximately 100 people became ill and several died after consuming contaminated mussels. None of the known shellfish toxins were found to be involved in the outbreak; rather the toxic agent was identified as domoic acid $(71,72)$. The source of domoic acid was the diatom Pseudo-nitzschia multiseries (formerly known as Nitzschia pungens $f$. multiseries) $(73,74)$. Domoic acid is a water-soluble tricarboxylic amino acid that acts as an analog of the neurotransmitter glutamate and is a potent glutamate receptor agonist. Domoic acid is related both structurally and functionally to the excitatory neurotoxin kainic acid isolated from the red macroalga Digenea simplex (75). Seven congeners to domoic acid have been identified (Figure 1E). Of these, three geometrical isomers, isodomoic acids $\mathrm{D}, \mathrm{E}$, and $\mathrm{F}$ and the C5' diasteriomer are found in addition to domoic acid in small amounts in both the diatom and in shellfish tissue $(76,77)$.

The symptoms of ASP include gastrointestinal effects (e.g., nausea, vomiting, diarrhea) and neurologic effects such as dizziness, disorientation, lethargy, seizures, and permanent loss of short-term memory. Domoic acid binds with high affinity to both kainate $\left(K_{d}-5 \mathrm{nM}\right)$ and $\alpha$-amino-3-hydroxy-5methyl-4-isoxazoleproprionic acid $\left(K_{d}\right.$ $9 \mathrm{nM})$ subtypes of glutamate receptor $(78,79)$. Persistent activation of the kainate glutamate receptor results in greatly elevated intracellular $\mathrm{Ca}^{2+}$ through cooperative interactions with $N$-methyl-D-aspartate and non- $N$-methyl-D-aspartate glutamate receptor subtypes followed by activation of voltage dependent calcium channels $(80)$. Neurotoxicity due to domoic acid results from toxic levels of intracellular calcium, which leads to neuronal cell death and lesions in areas of the brain where glutaminergic pathways are heavily concentrated. The $\mathrm{CA} 1$ and $\mathrm{CA} 3$ regions of the hippocampus, an area responsible for learning and memory processing, are particularly susceptible (81). However, memory deficits occur at doses below those causing structural damage (82). In rats, the $\mathrm{LD}_{50}$ (intraperitoneally) for domoic acid is $4 \mathrm{mg} / \mathrm{kg}$, whereas the oral potency is substantially lower $(35-70 \mathrm{mg} / \mathrm{kg}$ ) (83). In the 1987 outbreak, human toxicity occurred at $1-5 \mathrm{mg} / \mathrm{kg}$, suggesting that susceptible individuals are more sensitive than rodent models to the oral toxicity of domoic acid. Individuals found most susceptible were the elderly and those with impared renal function resulting in poor toxin clearance. A predisposing factor of impaired renal clearance is consistent with results observed in studies on experimental animals (84).

No human outbreaks of ASP have occurred since the original 1987 incident in Canada. However, since the 1987 outbreak, domoic acid has been identified as the causative agent in the mass mortality of pelicans and cormorants in Monterey Bay, California, in $1991(85,86)$ and in the extensive die-off of California sea lions in the same region in $1998(87,88)$. In both instances the vector for toxin transfer was anchovy. The causative organism in both the 1991 and 1998 mortality events was identified as another member of the same diatom genus, Pseudo-nitzschia australis. At least seven species of Pseudo-nitzschia are now recognized as domoic acid producers. These toxinproducing Pseudo-nitzschia species have since been identified in widely diverse geographic areas around the world, including New Zealand, Denmark, Spain, Scotland, Japan, and Korea (89). The presence of Pseudonitzschia in New Zealand was recorded as early as 1959 . However, domoic acid was not detected in New Zealand until after implementation of a comprehensive marine toxin monitoring program following the unprecedented NSP shellfish poisoning event in 1993. Domoic acid in New Zealand mussels and scallops occasionally reaches levels that result in shellfish bed closures (90).

\section{Pfiesteria and Estuary-Associated Syndrome}

Pfiesteria piscicida, a fish-killing dinoflagellate first identified in aquaculture tanks in North Carolina $(91,92)$, has been linked to fish kills in the mid-Atlantic region of the United 
States and is characterized by the presence of open, ulcerative lesions (93). Pfiesteria has been termed an "ambush predator" because it is believed to release a toxin that narcotizes or kills fish and then phagocytizes the sloughed tissue from its prey (94). Pfiesteria has a complicated life cycle with numerous life cycle stages $(94,95)$ including resting cysts, freeswimming flagellates (toxic and nontoxic), and amoeboid forms in which an amoeboid form is the dominant life-cycle stage. The cyst stage is viable under extreme conditions and is induced to excyst to form the toxic flagellate stage in the presence of fish. Subsequent depletion of its food supply results in rapid encystment of the flagellate. The identity of the putative chemical stimulus for Pfiesteria excystment has not yet been elucidated.

In addition to its effects on fish, Pfiesteria has been linked to a human intoxication syndrome, with symptoms that include fatigue, headache, respiratory irritation, skin lesions or burning sensations on contact, disorientation, and memory loss (96). An epidemiologic study of people exposed to Pfiesteria or Pfiesteria-associated water demonstrated severe impairment in cognitive functions compared to those of unexposed individuals from the same occupational, educational, and geographic area (97). Because of the remaining uncertainty regarding the causal role of Pfiesteria in these impairments, these symptoms have conservatively been termed estuaryassociated syndrome (98). Experimental injection of rats with Pfiesteria-containing aquarium water resulted in neurocognitive impairment in the rats when they were tested using a radial-arm maze (99). The toxins responsible for fish lethality or neurologic symptoms have not yet been identified. There is currently no evidence that toxicity is transferred through food.

Pfiesteria differs from the previously discussed dinoflagellates in that it is a nonphotosynthetic, heterotrophic dinoflagellate. Nonetheless, there is compelling evidence that its occurrence at toxic levels coincides with the eutrophication of coastal waters through intensive swine and poultry agriculture in areas of North Carolina and Maryland. Lagoon-stored and land-applied wastes from poultry and swine are a major source of nitrogen input from both runoff and atmospheric deposition and are suspected of supporting enhanced growth of autotrophic algae that in turn support the proliferation of Pfiesteria $(4,100)$. The study of Pfiesteria piscida has led to recognition of the widespread occurrence of heterotrophic dinoflagellates in estuarine waters, referred to as the Pfiesteria-like complex. Pfiesteria-like dinoflagellates have been documented on the east coast of the United States from Long
Island to Florida. The historical distribution of these dinoflagellates is not known nor is their toxicity or their role(s) in fish kills firmly established at this time.

\section{Global Increase in the Occurrence of Algal Toxins}

Figure 2 illustrates the change in global distribution of the occurrence of algal toxins of human health concern over the past three decades. Of particular significance is the occurrence of novel toxic algal syndromes not previously known as well as expansion of a number of toxin classes from the northern to the southern hemisphere during this time frame. It is important to note that this distributional map is a composite picture that reflects both increases in reports due to increased monitoring for toxins as well as true geographic expansions in the occurrence of toxic outbreaks. Newly established or expanded research and monitoring programs for algal toxins have been significant in identifying the presence of toxic or potentially toxic organisms in places never before documented. For example, New Zealand had no reported algal toxins in the 1970s but following an unprecidented toxic outbreak in 1992 established a comprehensive monitoring program that has since identified four or the five major toxin classes in shellfish at levels sufficient to cause occasional closures of shellfish harvest. Improvement in toxin detection methods has further contributed to expanded ranges reported in Figure 2. For example, the occurrence of ASP was unknown until the 1987 outbreak in Canada. It has subsequently been implicated in bird (1991) and marine mammal (1998) mortalities on the west coast of North America. Although these mortality
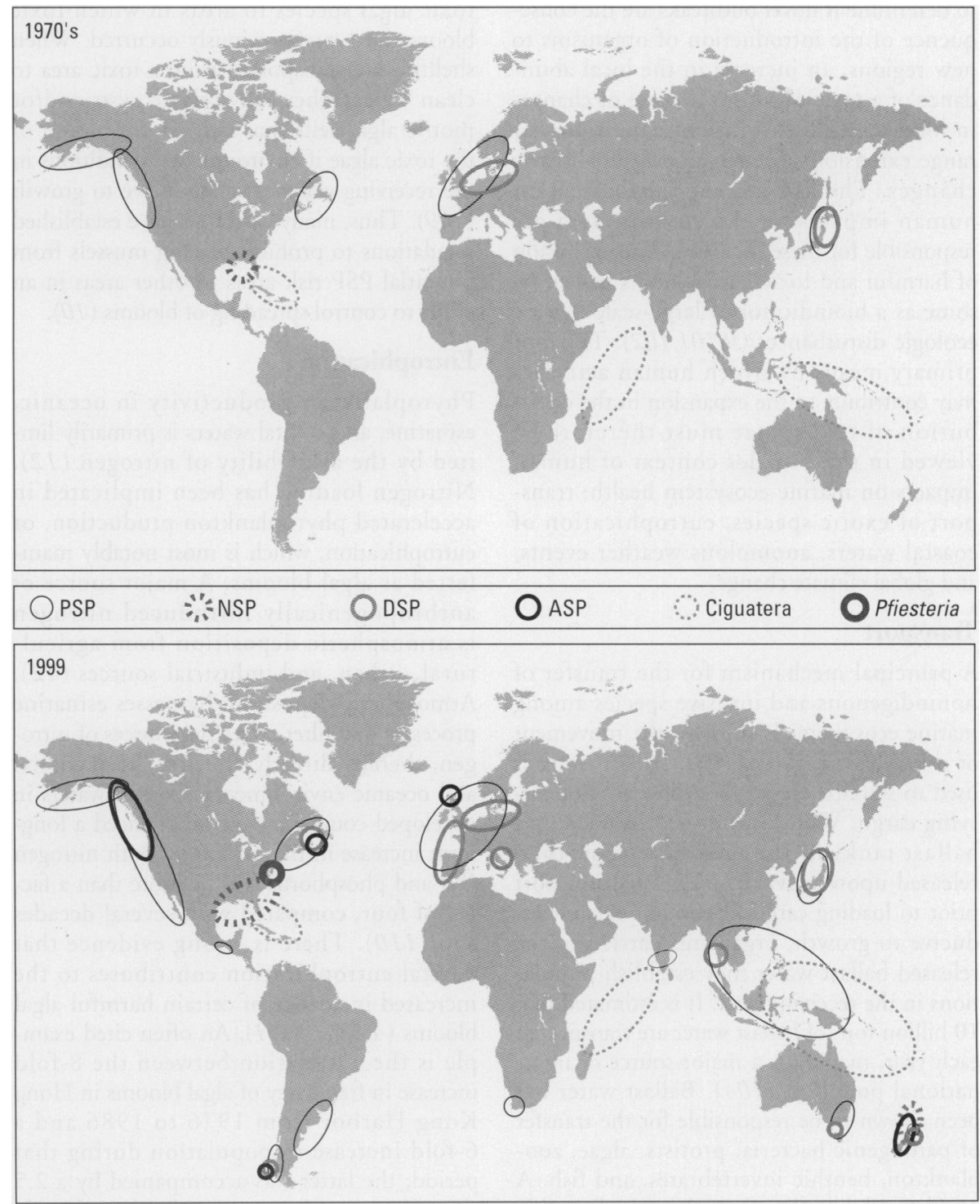

Figure 2. Global increase in reported incidence of algal toxins. Encircled areas indicate where outbreaks have occurred or toxin has been detected at levels sufficient to impact human or environmental health. 
events raise significant alarm in light of the apparent increase in the global impacts of algal toxins, unexplained episodic marine mammal mortality events, some of which appear to have similarities to the ASP-associated events, have occurred every few years on the west coast of North America for the past several decades (87). Thus, retrospective analysis of tissues from earlier mortality events, where available, may provide insight into the historical impacts of toxic blooms of Pseudonitzschia in this region.

In other cases, the distributions shown in Figure 2 are expansions in the known geographic range of toxic algal species at concentrations sufficient to impact human or environmental health. The expansions of PSP in southeast Asia and South America are key examples. The causes of these expansions are not well defined. The lack of long-term phytoplankton data often hinders the ability to determine if novel outbreaks are the consequence of the introduction of organisms to new regions, an increase in the local abundance of a toxic organism because of changes in local or regional nutrient conditions, or range extensions due to large-scale climatic changes. The key issue is to what extent human impacts on the environment are responsible for these increases. The expansion of harmful and toxic algal blooms is seen by some as a bioindicator of large-scale marine ecologic disturbances $(9,101,102)$. The four primary means by which human activities may contribute to the expansion in the distribution of toxic algae must therefore be viewed in the broader context of human impacts on marine ecosystem health: transport of exotic species, eutrophication of coastal waters, anomolous weather events, and global climate change.

\section{Transport}

A principal mechanism for the transfer of nonindigenous and invasive species among marine ecosystems is through the movement of ships' ballast water (103). Ballast water is used to stabilize ships when they are not carrying cargo. Water is pumped into a ship's ballast tanks in the port of origin, then released upon arrival at its destination port prior to loading cargo. If conditions are conducive to growth, organisms carried in the released ballast water may establish populations in the receiving port. It is estimated that 10 billion tons of ballast water are transported each year, making it a major source of international pollution (104). Ballast water has been shown to be responsible for the transfer of pathogenic bacteria, protists, algae, zooplankton, benthic invertebrates, and fish. A number of these invasions have had significant ecologic and economic impacts (105) or human health effects (106). Transport of toxic algal cells and cysts in the ballast water of ships is a documented mode of transfer of toxic dinoflagellates and diatoms to previously unaffected regions $(30,107,108)$ and a likely source of PSP in Australian waters. To address this issue, open ocean exchange of ballast water has been recommended by the International Maritime Organization (IMO), under current voluntary guidelines, as an effective means to minimize the introduction of exotic species (104). Further, a joint study group on ballast water and sediments by the International Council for Exploration of the Seas, the Intergovernmental Oceanographic Commission, and the IMO has since been established to develop mandatory ballast water guidelines.

Perhaps the most direct human impact on the distribution of toxic algal species is through the transfer of molluscan shellfish from growing waters in an area endemic to toxic algal species to areas in which toxic blooms have not previously occurred. When shellfish are transported from a toxic area to clean waters, they may release cysts and/or motile algal cells that may seed a bloom of the toxic algae if environmental conditions in the receiving waters are conducive to growth (109). Thus, many countries have established regulations to prohibit placing mussels from potential PSP risk areas to other areas in an effort to control spreading of blooms (10).

\section{Eutrophication}

Phytoplankton productivity in oceanic, estuarine, and coastal waters is primarily limited by the availability of nitrogen (12). Nitrogen loading has been implicated in accelerated phytoplankton production, or eutrophication, which is most notably manifested as algal blooms. A major source of anthropogenically introduced nitrogen is atmospheric deposition from agricultural, urban, and industrial sources (12). Atmospheric deposition by-passes estuarine processes that filter terrestrial sources of nitrogen, thereby directly affecting both coastal and oceanic environments. Coastal waters in developed countries have experienced a longterm increase in the loading of both nitrogen $(\mathrm{N})$ and phosphorus $(\mathrm{P})$, by more than a factor of four, compared with several decades ago (110). There is strong evidence that coastal eutrophication contributes to the increased incidence of certain harmful algal blooms $(4,8,9,12,111)$. An often cited example is the correlation between the 8 -fold increase in frequency of algal blooms in Hong Kong Harbor from 1976 to 1986 and a 6 -fold increase in population during that period; the latter was accompanied by a 2.5 times increase in nutrient loading (112). Although long-term data sets on phytoplankton assemblages are not available for many areas, changes in dinoflagellate cyst assemblages in surface sediments can be used to document eutrophication, as shown in Tokyo Bay (113). This approach was critical in identifying Gymnodinium catenatum as an introduced organism in Australian waters and is currently being employed to establish the history of PSP-producing Pyrodinium blooms in Southeast Asia.

Not only is the total concentration of enhanced nutrients of significance, but the altered ratios of these nutrients relative to those of other nutrients such as silica are also relevant. Long-term data sets in northern Europe strongly support the hypothesis that decreases in Si:N and Si:P ratios favor the growth of flagellates over silica-dependent diatoms $(9,111,114)$. Similar observations have recently been made in conjunction with Mississippi River input to the Gulf of Mexico (115). However, the role of coastal eutrophication in the increased incidence of harmful algal blooms may not be generalized to all $\mathrm{HAB}$ species. For example, there currently is no strong evidence to suggest that eutrophication of coastal waters contributes to PSP (Alexandrium tamarense) or NSP (Gymnodinium breve) blooms that originate in oligotrophic waters. The frequency and persistence of red tides on the west coast of Florida, for example, do not appear to have changed over the last 120 years (Figure 3). Each of the major range expansions of these organisms in North America has coincided instead with unusual climatic events $(11,43)$.

\section{Anomolous Weather Events}

It is well established that many human disease outbreaks peak during unusual climatic events such as drought, storm events that produce heavy rainfall, and El Niño $(57,106,116)$. Similarly, El Niño events are linked with the occurrence of diseases in marine species, including coral bleaching and shellfish diseases, and possibly marine mammal mortality events (102). El Niño occurs when prevailing easterly winds of the tropical Pacific fail. This ultimately suppresses upwelling of cold nutrient-rich water in the eastern Pacific and creates a pool of warm water in the west. Global precipitation changes as a consequence of El Niño are generally increased rainfall in Southeast Asia and drought in Australia, Africa, and India. The occurrence and/or expansion of human intoxication by PSP and CFP in the Indo-Pacific have been compellingly linked to the occurrence of El Niño conditions $(28,57)$. Historically, El Niño events have occurred at a frequency of one to two per decade. However, since the mid1970 s they have occurred more frequently and have persisted longer. The strongest recorded El Niño events (1982-1983 and 1997-1998) occurred during the past two decades, a period 
during which the sea surface temperatures rose and the incidence of HABs increased. The cooccurrence of these events late in this century has led to speculation that global warming may be an underlying cause $(101,102)$.

\section{Global Climate Change}

An observed increase in the global average temperature during the past century $\left(0.8^{\circ} \mathrm{C}\right.$ between 1889 and 1990) concurrent with industrialization suggests that the world may be entering a period of global warming to which human activities have contributed through production of greenhouse gases $(117,118)$. The oceans, because of their capacity as heat reservoirs, both influence and respond to global climate through thermohaline circulation, which recirculates nutrients, oxygen, and $\mathrm{CO}_{2}$. Long-term increases in sea surface temperature are predicted to modify the behavior of global oceanic circulation, which will further alter marine environmental regimes (46). The recent increases in frequency and emergence of novel diseases affecting marine organisms, from coral bleaching to shellfish pathogens, are believed to be linked to climate change $(101,102)$. The role of global warming in the expansion of toxic algal blooms is difficult to test, however, because of the complexity of overlying issues. First, the issue of increased reporting of toxic algal incidents must be factored out. In addition, increased utilization of coastal regions must be taken into account. Currently, approximately $50 \%$ of the U.S. population resides within the coastal zone, and this figure is predicted to increase. Thus, in some instances, the increased human health impacts of toxic algal blooms are a result of increased human exposure to preexisting bloom activity rather than to increased bloom activity, as is the case for the rapidly developing west coast of Florida. Changes in local environment due to coastal development or eutrophication also must be

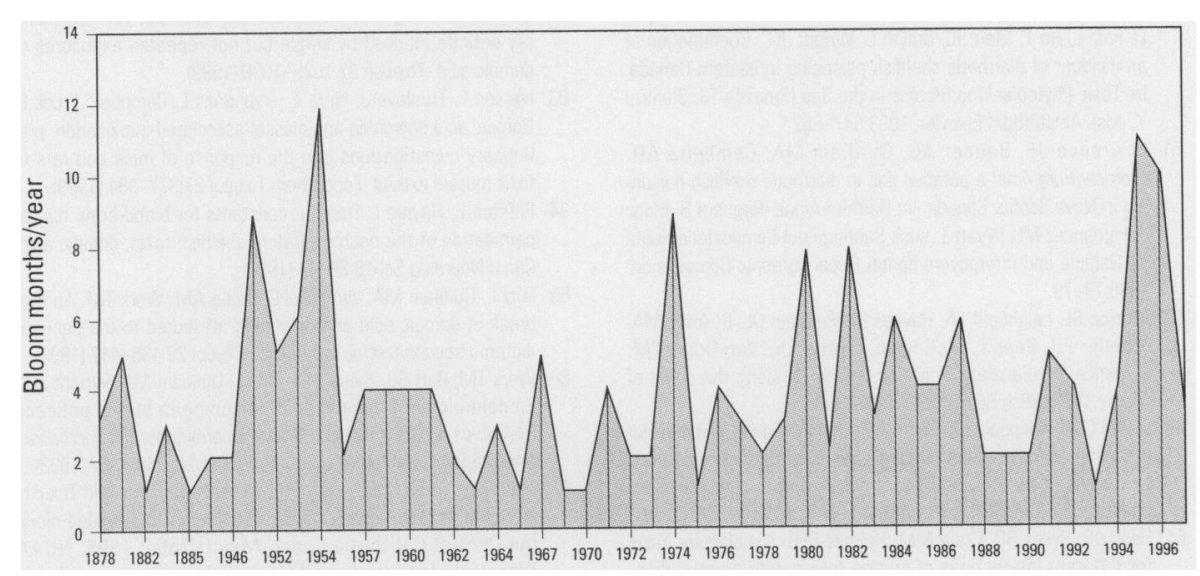

Figure 3. Occurrence of Gymnodinium breve red tides on the west coast of Florida (1878-1996), in months per year Data from Steidinger (119).

factored out from large-scale climatic changes. Many areas of the world where toxic blooms have recently expanded are areas used heavily for aquaculture. Aquaculture activity not only results in localized nutrient enrichment that may encourage growth of toxic species but places the vector for transmission of toxin to humans in this enriched environment. Finally, many areas of the world where toxic blooms have recently expanded lack long-term historical phytoplankton records with which to determine the origins of recent toxic algal blooms. Many of the time series available that might be useful for quantifying changes in the frequency of toxic blooms are no more than a few decades in length, not a sufficiently long period of time to factor out interannual to decadal variability in climate and phytoplankton abundance (13). Therefore, until longer time series are available, it will be difficult to demonstrate definitively that the increases observed are true long-term increases as opposed to recent responses to interannual or decadal climate variability. The distribution of fossil cysts of certain toxic dinoflagellate species has yielded useful insight into their distribution during previous warmer climate regimes and long-term variability in abundance; thus, paleoecology may be a useful tool for developing potential distributional maps that might be encountered under warmer global conditions $(8,46)$.

\section{Conclusions}

Marine algal toxins impact human health through seafood consumption and respiratory routes. The apparent increase in their occurrence over the past three decades has raised alarm. A key issue is whether the increase in the occurrence of toxic algal blooms reflects large-scale marine ecologic disturbance due to human activities and whether these trends can be reversed. The environmental conditions that trigger toxic algal blooms are not well

Environmental Health Perspectives - Vol 108, Supplement 1 - March 2000 understood and differ between different algal species, making generalizations inappropriate. Thus, insight into physiology and bloom dymanics must be addressed for each toxic species. It is clear in some cases that human activities may directly contribute to the occurrence of favorable growing conditions for these microalgae. In other cases, the potential indirect role of human activities through large-scale changes in our global environment remains viable but is difficult to establish. Insight into the historical distributions of toxic species through cyst analysis and molecular genetics may help distinguish between changes in geographic range of organisms and proliferation due to changes in local environmental conditions favoring bloom formation. Establishment of algal and toxin monitoring programs worldwide in the past two decades should assist in providing time series needed to assess interannual and long-term variability in algal and toxin occurrence.

\section{References and Notes}

1. Ahmed FE. Seafood Safety. Washington, DC:National Academy Press, 1991:432 pp.

2. Landsberg JH. Neoplasia and biotoxins in bivalves: Is there a connection? J Shellfish Res 15:203-230 (1996).

3. Landsberg JH, Balazs GH, Steidinger KA, Baden DG, Work TM, Russel DJ. The potential role of natural tumor promotors in marine turtle fibropapillomatosis. J Aquat Anim Health 11:199-210 (1999).

4. Burkholder JM. Implications of harmful microalgae and heterotrophic dinoflagellates in management of sutainable fisheries. Ecol Appl 8:S37-S62 (1998)

5. Edmunds, JSG, McCarthy RA, Ramsdell JS. Ciguatoxin reduces larval survivability in finfish. Toxicon 37:1827-1832 (1999).

6. Smayda TJ. Harmful algal blooms: their ecophysiology and general relevance to phytoplankton blooms in the sea. Limno Oceanogr 42:1137-1153 (1997)

7. Anderson DM. Toxic algal blooms and red tides: a global perspective. In: Red Tides: Biology, Environmental Science and Toxicology (Okaichi T. Anderson DM, Nemoto T, eds). New York:Elsevier, 1989;11-16.

8. Hallegraeff GM. A review of harmful algal blooms and their apparent global increase. Phycologia 32:79-99 (1993).

9. Smayda TJ. Novel and nuisance phytoplankton blooms in the sea: evidence for a global epidemic. In: Toxic Marine Phytoplankton (Graneli E, Sundstrom B, Edler L, Anderson DM eds). New York:Elsevier, 1990;29-40

10. Shumway SE. A review of the effects of algal blooms on shellfish and aquaculture. J World Aquaculture Soc 21:65-1104 (1990)

11. Anderson DM. Red tides. Sci Am 271:52-58 (1994).

12. Pearl HW. Whitall DR. Anthropogenically-driven atmospheric nitrogen deposition, marine eutrophication and harmful algal bloom expansion: is there a link? Ambio 28:307-311 (1999).

13. Richardson K. Harmful or exceptional phytoplankton blooms in the marine ecosystem. Adv Mar Biol 31:301-385 (1997)

14. Nisbet IC. Paralytic shellfish poisoning: effects on breeding terns. Condor 85: 338-345 (1983)

15. Geraci JR, Anderson DM, Timperi RJ, St. Aubin DJ, Early GA Prescott JH, Mayo CA. Humpback whales fatally poisoned by dinoflagellate toxin. Can J Fish Res Aquat Sci 46:1895-1898 (1989).

16. Kvitek RG, Beitler MK. A case for sequestering of paralytic shellfish toxins as a chemical defense. J Shellfish Res 7:629-636 (1988).

17. Kvitek RG, DeGange AR, Beitler MK. Paralytic shellfish poisoning toxins mediate feeding behavior in otters. Limnol Oceanogr 36:393-404 (1991).

18. Levin RE. Paralytic shellfish toxins: their origins, characteristics, and methods of detection: a review. J Food Biochem 15:405-417 (1992).

19. Gessner BD, Bell P, Doucette GJ, Moczydlowski E, Poli MA, Van Dolah FM, Hall S. Hypertension and identification of toxin in 


\section{F.M. VAN DOLAH}

human urine and serum following a cluster of mussel-associated paralytic shellfish poisoning outbreaks. Toxicon 35:711-722 (1997).

20. Hines HB, Naseem SM, Wannamacher RW Jr. ${ }^{3} \mathrm{H}$-Saxitoxinol metabolism and elimination in the rat. Toxicon 31:905-908 (1993).

21. Andrinolo D, Michea LF, Lagos N. Toxic effects, pharmacokinetics and clearance of saxitoxin, a component of paralytic shellfish poison (PSP), in cats. Toxicon 37:447-464 (1999).

22. Bengvides H, Prado L, Diaz S, Carreto, JI. An exceptional bloom of Alexandrium catenella in the Beagle Channel, Argentina. In: Harmful Algal Blooms (Lassus P, Arzul G, Erard E, Gentien P. Marcaillou C, eds). Paris:Lavoisier, 1995;113-119.

23. Starez-Isla BA. Personal communication

24. Carreto JI, Montoya NG, Cucchi Colleoni AD, Akselman R. Alexandrium tamarense blooms and shellfish toxicity in the Argentine Sea: a retrospective view. In: Harmful Algae (Reguera B, Blanco J, Fernandez M, Wyatt T, eds). Santiago de Compostella, Spain:Xunta de Galacia and Intergovernmental Oceanographic Commission, 1998;131-134.

25. Carreto Jl, Elbusto C, Sancho H, Carignan M, Cucci Colleoni D, de Marco S, Fernandez A. An exploratory analysis of the Mar del Plata shellfish toxicity area (1980-1990). Toxic Phytoplankton Blooms in the Sea (Smayda TJ, Shimizu Y, eds) New York:Elsevier, 1993;377-382.

26. Azanza R, Cruz L. Personal communication.

27. Furio EF, Fukuyo Y, Matsuoka K, Gonzales CL. The vertical distribution of resting cysts of PSP-producing dinoflagellate Pyrodinium bahamense var compressum in Manila Bay, Philippines. In: Harmful and Toxic Algal Blooms (Yasumoto T, Oashima Y, Fukuyo Y, eds). Paris:International Oceanographic Commission of UNESCO, 1996:185-188.

28. Maclean JL. Indo-Pacific red tides, 1985-1988. Mar Pollut Bull 20:304-310 (1989).

29. McMinn A, Hallegraeff GM, Thomson P, Jenkinson AV, Heijnis $H$. Cyst and radionucleotide evidence for the recent introduction of the toxic dinoflagellate Gymnodinium catenatum into Tasmanian waters. Mar Ecol Prog Ser 161:165-172 (1997).

30. Hallegreaff GM. Transport of toxic dinoflagellates via ships ballast water: bioeconomic risk assessment and efficacy of possible ballast water management strategies. Mar Ecol Prog Se 168:297-309 (1998).

31. Bolch CJS, Blackburn S, Hallegraeff GM, Vaillancourt RE. Genetic variation among strains of the toxic dinoflagellate Gymnodinium catenatum (Dinophyceae). J Phycol 35:356-367 (1999).

32. Poli MA, Mende TJ, Baden DG. Brevetoxins, unique activators of voltage-sensitive sodium channels, bind to specific sites in rat brain synaptosomes. Mol Pharmacol 30:129-135 (1986).

33. Trainer VL, Baden DG, Caterall WA. Identification of peptide segments of the brevetoxin receptor sie of rat brain sodium channels. J Biol Chem 269:19904-19909 (1994)

34. Rein K, Baden DG., Gawley RE. Conformational analysis of the sodium channel modulator, brevetoxin $A$, comparison with brevetoxin $B$ conformations, and a hypothesis about the common pharmacophore of the site 5 toxins. J Org Chem 59:2102-2106 (1994).

35. Rein K, Lynn B, Gawley R, Baden DG. Brevetoxin B: chemical modifications, synaptosome binding, toxicity, and an unexpected conformational effect. J Org Chem 59:2107-2113 (1994)

36. Gawley RE, Rein KS, Jeglitsch G, Adams DJ, Theodorakis EA Tiebes J, Nicolau KC, Baden DG. The relationship of brevetoxin 'length' and a-ring functionality to binding and activity in neuronal sodium channels. Chem Biot Interact 2:533-541 (1995).

37. Jeglitsch G, Rein K, Baden DG, Adams DJ. Brevetoxin 3 (PbTx-3) and its derivatives modulate single tetrodotoxin sensitive sodium channels in rat sensory neurons. J Pharmacol Exp Therap 284:516-525 (1998).

38. Steidinger KA, Carlson P, Baden D, Rodriguez C, Seagle J. Neurotoxic shellfish poisoning due to toxin in the clam Chion canellata. In: Harmful Algae (Reguera B, Blanco J, Fernande ML.Wyatt T, eds). Santiago del Compostella, Spain:Xunta de Galicia and Intergovernmental Oceanographic Commission 1998:457-458.

39. Steidinger KA, Vargo GA, Tester PA, Tomas CR. Bloom dynam ics and physiology of Gymnodinium breve with emphasis on the Gulf of Mexico. In: Physiological Ecology of Harmful Algal Blooms (Anderson DM, Cembella AD, Hallegraeff GM, eds) Berlin:Springer-Verlag, 1998;133-154.

40. Tester PA, Steidinger KA. Gymnodinium breve red tide blooms: initiation, transport, and consequences of surface circulation. Limnol Oceanogr 42:1039-1051 (1997).

41. Tester PA, Stumpf RP, Vukovich FM, Fowler PK, Turner JT. An expatriate red tide bloom: transport, distribution, and persis tance. Limnol Oceanogr 36:1053-1061 (1991).
42. Tester, PA, Geesey ME, Vukovich FM. Gymnodinium breve and global warming: what are the possibilities? In: Toxic Phytoplankton Blooms in the Sea (Smayda TJ, Shimizu Y, eds). 1993:67-72.

43. Tester PA. Climate change and marine phytoplankton. Ecosys Health 2:191-197 (1996)

44. Haywood A, MacKenzie L, Garthwaite I, Towers N. Gymnodinium breve 'look-alikes': three Gymnodinium isolates from New Zealand. In: Harmful and Toxic Algal Blooms (Yasumoto T, Oshima Y, Fukuyo Y, eds). Paris International Oceanographic Committee of UNESCO, 1996;227-230.

45. Bossart GD, Baden DG, Ewing RY, Roberts B. Wright SD. Brevetoxicosis in manatees (Trichechus manatus latirostros) from the 1996 epizootic: gross, histologic, and immunochemical features. Toxicol Pathol 26:276-282 (1998)

46. Sudarsanam S, Virca DG, March CJ, Srinivasan S. An approach to computer-based modeling: application to cathepsin. J Comput Aid Mol Des 6:223-233 (1992)

47. Yasumoto T, Nakajima I, Bagnis R, Adachi R. Finding of a dinoflagellate as a likely culprit of ciguatera. Bull Jpn Soc Sci Fish 43:1021-1026 (1977)

48. Lewis RJ, Holmes MJ. Origin and transfer of toxins involved in ciguatera. Comp Biochem Physiol 106C:615-628 (1993)

49. Freudenthal AR. Public health aspects of ciguatera poisoning contracted on tropical vacations by North American tourists. In: Toxic Marine Phytoplankton (Graneli E, Sundstron B, Edler L. Anderson DM, eds). New York:Elsevier, 1990;463-468

50. Vernoux, J-P. Lewis RL. Isolation and characterization of Caribbean ciguatoxins from the horse-eye jack (Caranx latus). Toxicon 35:889-900 (1997)

51. Dechraoui M-Y, Naar J, Pauillac S, Legrand A-M. Ciguatoxins and brevetoxins, neurotoxic polyether compounds active on sodium channels. Toxicon 37:125-143 (1999).

52. Legrand AM. Ciguatera toxins: origin, transfer through food chain and toxicity to humans. In: Harmful Algae (Reguera B, Blanco J, Fernandez ML. Wyatt T, eds). Santiago del Compostella:Xunta de Galacia and IIntergovernmental Oceanographic Commission, 1998;39-43.

53. Ruff TA. Ciguatera in the Pacific: a link with military activities. Lancet:201-205 (1989)

54. Kaly UL, Jones GP. Test of the effect of disturbance on ciguat era in Tuvalu. Mem Qd Mus 34:523-532 (1994).

55. Kohler ST, Kohler CC. Dead bleached coral provides new surfaces for dinoflagellates implicated in ciguatera fish poisonings. Environ Biol Fishes 35:413-416 (1992)

56. Bagnis RS. Ciguatera fish poisoning: an objective witness of coral reef stress. In: Human Impacts on Coral Reefs: Facts and Recommendations (Salvat B, ed). French Polynesia:Antenne Museum, 1987:241-253.

57. Hales S, Weinstein P. Woodward A. Ciguatera (fish poisoning), EI Niño, and Pacific sea surface temperatures. Ecosys Health 5:20-25 (1999).

58. Yasumoto T, Oshima Y, Yamaguchi M. Occurrence of a new type of shellfish poisoning in Japan and chemical properties of the toxin. In: Toxic Dinoflagellate Blooms (Taylor D, Seliger HH, eds). Amsterdam:Elsevier, 1979;495-502.

59. Yasumoto T, Oshima Y, Sugawara W, Fukuyo Y, Oguri H Igarishi T, Fujita N. Identification of Dinophysis fortii as the causative organism of diarrhetic shellfish posioning. Bull Jpn Soc Sci Fish 46:1405-1411 (1980).

60. Quilliam MA, Gilgan M, Pleasance S, Defrietas ASW, Douglas D. Fritz L, Hu T, Marr JC, Smyth C, Wright JLC. Confirmation of an incident of diarrhetic shellfish poisoning in eastern Canada. In: Toxic Phytoplankton Blooms in the Sea (Smayda TJ, Shimizu Y. eds). Amsterdam:Elsevier, 1993:547-552.

61. Lawrence JE, Bauder AG, Quilliam MA Cembella AD. Prorocentrum lima: a putative link to diarrhetic shellfish poisoning in Nova Scotia, Canada. In: Harmful Algae (Reguera B, Blan J. Fernandez ML, Wyatt T, eds). Santiago del Compostella:Xunta de Galacia and Intergovernmental Oceanographic Commission, 1998:78-79

62. Morton SL, Leighfield TA, Haynes BL, Petipain DL, Busman MA Moeller PD, Bean L, McGowan J, Hurst JL, Van Dolah FM. Evidence for diarrhetic shellfish poisoning along the coast of Maine. J Shellfish Res 18:679-684 (1999).

63. Gauss C-M, Sheppock JE, Nairn AC, Chamberlin RA. A molecular modeling analysis of the binding interactions between okadaic acid class of natural product inhibitors and the ser-thr phosphatases, PP1 and PP2A. Bioorg Med Chem 5:1751-1773 (1997).

64. Bagu JR, Sykes BD, Craig MM, Holmes CFB. A molecular basis for different interactions of marine toxins with protein phosphatase B1. Molecular models for bound moruporin, microcystins, okadaic acid and calyculin A. J Biol Chem 272:5078-5097 (1997)
65. Zhang Z, Zhao S, Long F, Zhang L, Bai G, Shima H, Nagao M, Lee EYC. A mutant of protein phosphatase- 1 that exhibits altered toxin sensitivity. J Biol Chem 269:16997-17000 (1994).

66. Wera S, Hemmings B. Ser/thr protein phosphatases. Biochem J 311:17-29 (1995)

67. Cohen P. Holmes CFB. Tsukitani Y. Okadaic acid: a new probe for the study of cellular regulation. Trends Biochem Sci 15:98-102 (1990).

68. Yasumoto T, Murata M, Oshima Y, Matsumoto G, Clardy J. Diarrhetic shellfish poisoning. In: Seafood Toxins (Regalis EP ed). Washington, DC:American Chemical Society, 1984;207-214.

69. Suganuma M. Fujiki H, Suguri H, Yoshizawa S, Hirota M Nakayasu M, Ojika M, Wakamatsu K, Yamada K, Sugimura T. Okadaic acid - an additional non-phorbol-12-tetradecanoate13-acetate-type tumor promoter. Proc Natl Acad Sc 85:1768-1771 (1988)

70. Fujiki H, Suganuma M, Suguri H, Yoshizawa S, Tagai K, Uda N, Wakamatsu K, Yamada K, Murata M. Yasumoto T, et al. Diarrhetic shellfish toxin, dinophysistoxin-1, is a potent tumo promotor on mouse skin. Jpn J Cancer Res 79:1089-1093 (1988).

71. Wright JLC, Boyd RK, Defrietas ASW, Falk M, Foxall RA. Jamieson WD, Laycock MV, McCulloch AW, McInnes AG, Odense $P$, et al. Identification of domoic acid, a neuroexcitatory amino acid, in toxic mussels from eastern P.E.I. Can J Chem 67:481-490 (1989)

72. Perl TM, Bedard L, Kosatsky T, Hockin JC. Todd ECD, Remic RS. An outbreak of toxic encephalopathy caused by eating mussels contaminated with domoic acid. $\mathrm{N}$ Engl $\mathrm{J}$ Med $322: 775-1780$ (1990)

73. Subba-Rao DV, Quilliam MA, Pocklington R. Domoic acid B a neurotoxic amino acid produced from the marine daitom Nitzschia pungens in culture. Can J Fish Aquat Sci 45:2076-2079 (1988)

74. Bates SS, Bird CJ, Defrietas ASW, Foxall R, Gilgan M, Hanic LA, Johnson GR, McCulloch AW. Odense P, Pocklington R, et al. Pennate diatom Nitzschia pungens as the primary source of domoic acid, a toxin in shellfish from eastern Prince Edward Island, Canada. J Fish Aquat Sci 46(7):1203-1215 (1989).

75. Murakami S, Takemoto T, Shimizu Y. Studies on the effective principles of Diagenea simplex Aq. I: Separation of the effective fraction by liquid chromatography. J Pharmacol Soc Jpn 73:1026-1028 (1953)

76. Wright JLC, Falk M, McInnes AG, Walter JA. Identification of isodomoic acid $\mathrm{D}$ and two new geometrical isomers of domoic acid in toxic mussels. Can J Chem 68:22-25(1990)

77. Walter JA, Falk M, Wright JLC. Chemistry of the shellfish toxin domoic acid: characterization of related compounds. Can J Chem 72:430-436 (1994).

78. Hampson DR, Huang X, Wells JW. Walter JA, Wright JLC. Interaction of domoic acid and serveral derivatives of kainic acid and AMPA binding sites in rat brain. Eur J Pharmacol 218:1-8 (1992).

79. Hampson DR, Manalo JL. The activation of glutamate receptors by kainic and domoic acid. Natural Toxins 6:153-158 (1998).

80. Xi D, Ramsdell JS. Glutamate receptors and calcium entry mechanisms for domoic acid in hippocampal neurons. Neuroreport 7:1115-1120 (1996)

81. Peng YG, Taylor TB, Finch RE, Switzer RC, Ramsdell JS Neuroexcitatory and neurotoxic actions of the amnesic shellfish poison, domoic acid. Neuroreport 5:981-985 (1994)

82. Clayton EC. Peng Y-G, Means LW, Ramsdell JS. Working memory deficits induced by single but not repeated exposures to domoic acid. Toxicon 37:1025-1039 (1999)

83. Iverson F, Truelove J, Nera E, Tryphonas L, Campbell J, Lok E. Domoic acid poisoning and mussel-associated intoxication: preliminary investigations into the response of mice and rats to toxic mussel extract. Food Chem Toxicol 27:377-384 (1989)

84. Preston E, Haynie I. Transfer constants for blood-brain barrier permeation of the neuroexcitatory shellfish toxin, domoic acid. Can J Neurolog Sci 18:39-44 (1991).

85. Fritz L, Quilliam MA, Wright JLC, Beale AM, Work TM. An outbreak of domoic acid and poisoning attributed to the pennate diatom Pseudonitzschia australis. J Phycol 28:438-442 (1992).

86. Work TM, Barr BB, Beale AM, Fritz L, Quilliam MA, Wright JLC. Epidemiology of domoic acid poisoning in brown pelicans (Pelicanus occidentalis) and Brandt's cormorants (Phalacrocorax pencillatus) in California. J Zool Wildlife Med 24:54-62 (1993)

87. Gulland F. 1999. Unusual Mortality Event - Domoic Acid Toxicity in California Sea Lions (Zalophus californianus) Stranded along the Central California Coast, May-October 1998. NOAA Tachnical Memorandum NMFS-OPR-8. Wahington, DC:U.S. National Marine Fisheries Service, 1999;30 pp

88. Scholin CA, Gulland F, Doucette GJ, Benson S, Busman M, Chavez FP, Cordaro J, DeLong R, DeVogelaere A, Harvey J 
et al. Mortality of sealions along the California coast linked to a toxic diatom bloom. Nature 403:80-83 (2000).

89. Bates SS. Bloom dynamics and physiology of domoic acid producing Pseudo-nitzschia species. In: Physiological Ecology of Harmful Algal Blooms (Anderson DM, Cembella AD, Hallegraeff GM, eds). New York:Springer-Verlag, 1998;267-292.

90. Rhodes L, Scholin C, Garthwaite I. Pseudo-nitzschia in New Zealand and the role of DNA probes and immunoassays in refining marine biotoxin monitoring programmes. Natural Toxins 6:105-111 (1998)

91. Smith S, Noga E, Bullis RA. Mortality in Talapia due to a toxic dinoflagellate bloom [Abstract]. Proceedings of the Third International Colloquium on Pathology in Marine Aquaculture, Gloucester Point, Virginia. 1998;167-168.

92. Noga EJ. Fungal diseases of marine and estuarine fishes. In Pathobiology of Marine and Estuarine Organisms (Couch JA Fournie JW, eds). Boca Raton, FL:CRC Press, 1993:85-100.

93. Burkholder JM, Noga EJ, Hobbs CW, Glasgow HB, Smith SA New phantom dinoflagellate is the causative agent of major estuarine fish kills. Nature 358:407-410 (1992).

94. Burkholder JM, Glasgow HB Jr. Pfiesteria piscicida and other Pfiesteria-like dinoflagellates: behavior, impacts, and environmental controls. Limnol Oceanogr 42:1052-1075

95. Burkholder JM, Glasgow HB Jr. Trophic controls on stage trans formations of a toxic amnush-predator dinoflagellate. J Euk Microbiol 44:200-205.

96. Glasgow HB, Burkholder JM, Schmechel DE, Tester PA, Ruble PA. Insidious effects of a toxic dinoflagellate on fish survival and human health. J Toxicol Environ Health 46:101-122 (1995).

97. Grattan LM, OIdach D, Perl TM, Lowitt MH, Matuszak DL, Dickson C, Parrott C, Shoemaker RC, Kauffman CL, Wasserman $\mathrm{MP}$, et al. Learning and memory difficulties after environmental exposure to waterways containing toxin-producing Pfiesteria and Pfiesteria-like dinoflagellates. Lancet 352:532-539 (1998).

98. Centers for Disease Control. Results of the public health response to the Pfiesteria workshop-Atlanta, Georgia, September 29-30, 1997. Morb Mort Weekly Rep 46:951-952 (1997).

99. Levin ED, Schmechel DE, Burkholder JM, Glasgow HB, DeamerMelia NJ, Moser VC. Harry GJ. Persisting learning deficits in rate after exposure to Pfiesteria piscicida. Environ Health Perspect 1015:1320-1325 (1997).

100. Pearl HW. Coastal eutrophication and harmful algal blooms: importance of atmospheric disposition and groundwater as "new" nitrogen and other nutrient sources. Limnol Oceanogr 42:1154-1165 (1997).

101. Epstein P, Sherman B, Spanger-Siegfried E, Langston A, Prasad $S$, Mckay B. Marine ecosystems: emerging diseases as indicators of change. Year of the Oceans Special Report. Washington, DC:NOAA Office of Global Programs, 1998;85 pp.

102. Harvell CD, Kim K, Burkholder JM, Colwell RR, Epstein PR, Grimes DJ, Hofmann EE, Lipp EK, Osterhaus AD, Overstreet RM, et al. Marine ecology-emerging marine diseases-climate links and anthropogenic factors [Review]. Science 285:1505-1510 (1999).

103. Carlton JT, Geller JB. Ecological roulette: the global transport of nonindigenous marine organisms. Science 261:78-82 (1993).

104. Rigby GR, Taylor AH, Hallegraeff GM, Mills P. Progress in research and management of ships' ballast water to minimise the transfer of toxic dinoflagellates. In: Harmful Marine Algal Blooms (Lassus P, Arzul G, Erard E, Gentien P, Marcaillou C, eds). Lavoisier:Paris, 1995;821-824

105. Ruiz GM, Carleton JT, Hines AH. Global invasions of marine and estuarine habitata by non-indiginous species: mechanisms, extent, and consequences. Am Zool 37:621-632 (1997).

106. Colwell R. Global climate and infectious disease: the cholera paradigm. Science 274:2025-2031 (1996).

107. Zhang FZ, Dickman M. Mid-ocean exchange of container vessel ballast water. 1: Seasonal factors affecting the transport of harmful diatoms and dinoflagellates. Mar Ecol - Prog Ser 176:243-251 (1999).

108. Dickman M, Zhang FZ. Mid-ocean exchange of container vessel ballast water. 2. Effects of vessel type in the transport of diatoms and dinoflagellates from Manzanillo, Mexico, to Hong Kong, China. Mar Ecol - Prog Ser 176:253-262 (1999).

109. Scarratt AM Scarratt DJ, Scarratt MG. Survival of live Alexandrium tamarense in mussel and scallop spat under simulated conditions. J Shellfish Res 12:383-388 (1993).

110. Nixon SW. Coastal marine eutrophication: a definition, socia causes and future concerns. Ophelia 41:199-220 (1995).

111. Reigman R. Species composition of harmful algal blooms in relation to macronutrient dynamics. In: Physiological Ecology of Harmful Algal Blooms (Anderson DM, Cembella AD, Hallegraeff GM, eds). New York:Springer-Verlag, 1998:475-488.

112. Lam CWY, Ho KC. Red tides in Tolo Harbor, Hong Kong. In: Red Tides: Biology, Environmental Science and Toxicology (Okaichi T, Anderson DM, Nemoto T, eds). New York:Elsevier, 1989;49-52.

113. Matsuoka K. Eutrophication process recorded in dinoflagellate cyst assemblages - a case of Yokohama Port, Tokyo Bay, Japan. Sci Total Environ 231:17-35 (1999)

114. Humbourg C, Tittekkot V, Cociasu A, Bodungen B. Effect of Danube River dam on Black Sea ecosystem structure. Nature 386:385-388 (1997)

115. Turner RE, Rabelais NN. Coastal eutrophication near the Mississippi Delta. Nature 368:619-621 (1994).

116. Epstein PR. Perspectives: Medicine - climate and health. Science 285:347-348 (1999).

117. National Research Council. Climate and weather, coastal haz ards, and public health. In: From Monsoons to Microbes: Understanding the Ocean's Role in Human Health. Washington DC:National Academy Press, 1999;17-42.

118. Mann ME, Bradley RS, Hughes MK. Global scale temperature patterns and climate forcing over the past six centuries. Nature 392:779-787 (1998)

119. Steindinger KA. Unpublished data. 